Relations industrielles

Industrial Relations

\title{
Pros and Cons
}

\section{Gilbert Levine}

Volume 30, numéro 4, 1975

URI : https://id.erudit.org/iderudit/028660ar

DOI : https://doi.org/10.7202/028660ar

Aller au sommaire du numéro

\section{Éditeur(s)}

Département des relations industrielles de l'Université Laval

\section{ISSN}

0034-379X (imprimé)

1703-8138 (numérique)

Découvrir la revue

Citer cet article

Levine, G. (1975). Pros and Cons. Relations industrielles / Industrial Relations, 30(4), 727-735. https://doi.org/10.7202/028660ar
Résumé de l'article

In this paper, the author examines some of the prosand cons of collective bargaining in University faculties.
Tous droits réservés (C) Département des relations industrielles de l'Universite Laval, 1975
Ce document est protégé par la loi sur le droit d'auteur. L'utilisation des services d'Érudit (y compris la reproduction) est assujettie à sa politique d'utilisation que vous pouvez consulter en ligne.

https://apropos.erudit.org/fr/usagers/politique-dutilisation/ 


\section{Collective Bargaining in University Faculties}

\section{Pros and Cons}

\section{Gilbert Levine}

In this paper, the author examines some of the pros and cons of collective bargaining in University faculties.

The topic of this paper first referred me to the question posed in the famous old union song that grew out of the struggle of the United Mine Workers Union : "Which Side are You On?»

I must admit that I had an initial reaction that placed me on the con side of the argument. That reasoning went something like this :

1) The working class has suffered, struggled, fought, and in many cases died, in the hundred year battle to gain free collective bargaining rights for the workers of Canada. Should the middle class academics of Canada simply be allowed to pick up the fruits of these working class struggles for collective bargaining without even a fight? Should the Johnny Come Latelies to collective bargaining be allowed to take over a worker collective bargaining system without some kind of struggle ?

2) Academics have traditionally viewed themselves as being independent of any broader socio-economic forces, that is, an independent "Community of Scholars» seeking the truth in an academic enclave. However, I view one of the main functions of a academe to enculturate students with the norms and values of our corporate society. Universities are used to infuse the dominant values and ideological outlook of our society, that is, the right to profit and private property and a general acceptance of the status quo among students. Indeed, the very evolution

LEVINE, G., Research Director, Canadian Union of Public Employees, Ottawa, Ont.

* Paper presented at the Canadian Industrial Relations Research Institute Annual Meeting, Edmonton, Alberta, June 1975. 
of university structures and the content of various academic disciplines can be directly related to the economic development of our corporate economy and its needs in various forms. Such being the case, should academics, who as a group I would describe as defenders of the status quo, be given the privilege of collective bargaining so that they may still further entrench their status quo positions?

3) The generally regressive tax system in Canada results in working class families paying the bulk of taxation, which is used among other things, to subsidize the education of middle and upper class students and middle class academies. Should this mechanism of collective bargaining, which has been developed by the working class, now be allowed to be used by middle class academics to further « rip off » the working class of Canada?

4) As the term states, collective bargaining implies a «collectivist 》 approach to solving problems. But is this collectivist approach not incompatible with the individualism of the academic jungle? Should not academes be allowed to continue the sport of knifing one another in the back as they fight up the ladder of academia ? Should not the academic apple polishers be allowed to advance themselves individually instead of being allowed the collective approach whereby they might all advance together?

So much for all my «con» thoughts on collective bargaining. However, reason soon got the better of me. My «con» thoughts on faculty bargaining began switching to «pro» thoughts as I began thinking of the late $\mathbf{C}$. Wright Mills analysis of the «proletarianization of the middleclass » and of formerly middle class occupations. What Mill's terrned the development of the middle-class «salariat» was and is in fact, the development of a middle class salaried employee stratum within the workingclass, almost as dependent and powerless as his hourly paid wage earner counterpart.

The development of the salariat represents a transformation of many occupations from independent professionals-intellectual workers - to a situation where they are salary (wage) earners structurally dependent on others to make a liveliehood. One has merely to recount the number of lawyers who become employees (not partners) in firms, accountants and engineers who are salary earners to appreciate that the era of the independent professional is over.

One of the key fundamental differences between the middle-class salariat and the worker remains the level of self-perception and conscious- 
ness, that is, «where do I fit in? 》 Workers rarely have such illusions of where they fit in. The middle-class intellectual and professional prides him/herself on being "different », on being a member of an elite. The transformation of many middle-class occupations into a dependency relationship (based on salary) with its corollary decline in status and income comes as a shock to many. To say that many middle-class occupations are today in a position characteristic of the more traditional industrial work force is a hammer-like blow to the fragile academic ego. After all middle-class faculty don't think of themselves, don't perceive of themselves as «employees» or «workers, » and why should they?

Faculty in the post World War 2 period have indeed been a priviledged elite. With the heady economy of the 1950's, with the tight labour market and grantsmanship of the 1960's professors became «academic entrepreneurs » with everything going for them.

Then came the end of this happy scenario. Under the pressure of inflation, taxes, the economic downturn, the reduction in students enrollment and non-renewal in contracts, the middle-class faculty soon realized that they were, in many ways, no better off than their industrial worker counterparts. The growth of university administrative bureaucracies placed the academic in an oppressive work place somewhat similar to the plant or office worker in industry. In fact, academics were nothing more than intellectual workers in an academic setting.

Therefore, as a trade unionist I therefore, must welcome these academic workers to the world of collective bargaining.

The second reason that I support faculty collective bargaining is that it will ensure academic freedom.

One of the most common reasons put forward by academics in opposition to collective bargaining is that it will diminish academic freedom. I take the opposit point of view. I believe real collective bargaining will not diminish but will enhance the possibilities of true academic freedom.

This fact has forcefully been brought home to me as a result of CUPE's first academic collective agreement. In the agreement negotiated between CUPE and Bathurst College in New Brunswick, there is a strong article on academic freedom. It is not some vague notion on academic freedom which exists in the minds of some academics. It is spelled out as a contractural right in the collective agreement and states in part : 
1. The board of trustees shall uphold the faculty's ... academic freedom to discuss controversial issue.

2. Nothing... shall be construed as interfering with the personal or professional civil rights or liberties of the academic staff.

3. The faculty member shall be entitled to complete freedom in the classroom in discussing his subject. He shall have the right to introduce into his teaching any matter related to his subject or the education of his students.

4. Faculty shall have sole responsibility to determine course content.

5. Academic staff shall be entitled to full freedom in research and in publication.

6. Academic staff shall be free from institutional censorship, discipline, harassment and intimidation.

And like every good collective agreement, the Bathurst College agreement contains a solid grievance and arbitration procedure to ensure that these rights are upheld.

Another reason I decided to support the concept of academic collective bargaining is that I am convinced it will help to democratize the university and will improve the quality of education. In stating this, I am again relying heavily on CUPE's experience at Bathurst College. The following are some of the provisions we were successful in obtaining in a first collective agreement.

1. Union representation on the college academic council and committes dealing with conditions of employment and departmental planing.

2. The basic salary shall not be reduced by any change which might be made in the academic calendar.

3. Class size and academic hours: The maximum class load for each fulltime staff member shall be 9 hours per week. The maximum contact hours, that is, class hours plus office hours, shall be 15 hours per week. Academic staff are not required to be on campus if classes, office hours, or administrative duties are not scheduled. The regular class size shall be limited to 40 students.

4. Maternity leave : A total of 6 months which may be extended for one academic year. All fringe benefits paid by the college 
during maternity leave. Normal salary continues during maternity leave with deductions from accumulated sick leave of 18 days per annum. On return from maternity, her former position, or equivalent position, is guaranteed.

5. Study leave : Leave shall be granted for one academic year at $30 \%$ of salary for good and sufficient cause to any academic with three or more years of seniority.

6. Sabbatical leave : Academic staff shall be entitled to a sabbatical leave every five years. In any academic year ten percent of the staff shall be eligible and will receive $60 \%$ salary increasing to $75 \%$ after 6 years plus full fringe benefits.

In addition to the above there is a long list of important benefits such as reimbursement for attendance at professional conventions, child care, curriculum review, free parking, faculty offices and clerical staff, paid dental plan, group life plan, long term disability plan and a shared pension plan plus 50\% discount at the bookstore.

None of these concepts are new. What is new is that, for the first time, many of these concepts have been embodied into a binding collective agreement, with the right of the faculty to grieve or arbitrate any violation. And further: These rights were not achieved by a faculty association in some affluent part of Canada. These rights and benefits were achieved in one of the most depressed parts of Canada - Northern New Brunswick.

These are the kinds of changes which will improve the quality of education through collective bargaining and for these reasons I support the principle.

However, in endorsing the principle of faculty collective bargaining, I want to ensure that I am endorsing «the real thing. » I endorse real collective bargaining by real trade unions. In order for faculty associations to become real unions will require a number of important changes.

\section{CAUT Will Have to Become A Union}

Although the Canadian Association of University Teachers represents only a tiny percentage of university faculty for collective bargaining purposes (at Manitoba, Carleton, St. Mary's and Notre Dame) it is still the largest organization representing academics for collective bargaining purposes in English Canada. However CAUT itself is not a 
trade union. It is a professional association. In law it is a corporation registered under the Corporation Act.

CAUT can not be everybody's friend. It can not be both a union and a professional association at the same time. By attempting to do so, it will inevitably weaken itself in carrying out either of these functions.

\section{Faculty Associations Will Have to Join the Organized Labour Movement}

Although trade unions have been traditionally seen as organizations for industrial workers to improve their conditions of employment, it has been overwhelmingly demonstrated in recent years that the same methods of organization and techniques of collective bargaining have application well beyond the sphere of industrial workers. It is for this reason that we have seen a tremendous upsurge in collective bargaining for white collar and professional workers, particularly in the public sector. And now the same methods and techniques that for years were used to improve conditions of employment for industrial workers are being used to improve the conditions of college and university employees from caretakers down to professors.

Despite the myth that there are great differences between an automobile assembly line worker and a professor, it is surprising to note the many similarities in their needs. Both groups of employees need a mechanism to improve their conditions of work. Both groups of employees need to democratize their places of work. Therefore, there is much more in common than one would normally expect.

There is another important area that trade unionists and faculty have in common. They are both covered by Provincial Labour Relations Acts which favour the employer and unjustly restrict unions from effectively representing their membership.

But more than this, there is one major factor which faculty members have in common with trade unionists, particulary trade union members employed in universities. Both groups have the same employer. The ultimate employer is the Board of Governors of the University or the Provincial Government, and often a combination of both.

If academic expects to be effective bargainers this can not be done in isolation from the rest of the labour movement. Faculty will have to join forces with organized labour, whichever group that may be on campus or in their province. This does not necessarily mean that the care- 
taker and the academic must or should belong to the same bargaining unit. In the labour movement there are many examples of two and sometimes three locals of the same union with a collective bargaining relationship with the same employer, sometimes each with its own contracts. But it will mean that in order to make collective bargaining viable in the higher educational systems, particulary in English Canada, will require in many instances, a major shift of attitudes among faculty members.

What was in the past, and what threatens in the future, to divide and isolate university professors from organized labour is the fact that, being middle-class and professional in outlook, results in an elitist mentality. The result of this mentality is that academics labour under the myth that they are better than other workers and deserve to be paid more. In a word, middle-class academics may well indeed unionize but it may be over the bodies of other workers. The urge to unionize comes from an elite and «protectionism» not from a sense of unity or solidarity with other segments of the university labour force.

Long before academics thought of unionization, most other university staff had the wisdom, courage, and vision to unionize. Some 20,000 members of the Canadian Labour Congress (CLC) affiliates are employees in post secondary institutions. The CLC's largest affiliate, the Canadian Union of Public Employees (CUPE) represents some 10,000 employees in 38 Universities.

CUPE's bargaining units range from what are called manual workers, for example, cleaners, groundmen, tradesmen, etc., to clerical employees who work in administrative offices, to clerical and technical employees in university libraries, to bargaining units of technicians and technologists and more recently to bargaining units of faculties in community colleges.

In the first instance there must be interunion solidarity on campus. If there isn't, the division will result in picking up the crumbs of the bargaining tables as academic and other staff unions fight it out.

It is well to keep in mind that faculty as a percentage of University labour force are a minority. By way of example the Dalhousie University staff outnumbers the academic staff $3: 1$. The point being simply that the faculty of Canadian Universities must view themselves in a broader context on campus - namely that they are a minority with many priviledges and that they will not be permitted to protect their middle-class interest by crawling over the bodies of other staff. The only way this 
confrontation can be avoided is if the bargaining agents for faculty has the foresight to such a serious and broad community of interest with other staff, instead of remaining in elitest isolation.

Further, unions of academics as part of the organized labour movement are desirable for the following reasons :

1. Unions are basically organizations of self-help. Unions can learn the technical knowledge, expertise, and research, etc of the academies. In turn, organized labour can offer academics a wealth of knowledge in organizing techniques, collective bargaining techniques, and most of all - a power base to change the status quo.

2. Affiliation with organized labour and participation in its activities will be a great step towards eliminating the narrowness of the academic and his remoteness from the real world and its real social problems. From the Union's part academic participation in labour it is bound to begin to eliminate the fears and suspicions which many in the ranks of labour have of academics and intellectuals.

3. As has been already stated, academics and unionists are fighting the same employer and united we can each do a better and more effective job. In this time of budgetary restraints in education we have two choices :

(i) Faculty and other staff can fight on another in an attempt to get a greater portion of the university budget. Following this course, both groups are bound to lose out.

(ii) The second alternative is to join forces and fight our mutual employer to increase, not decrease, the funds that are available for education.

Therefore, the main point is to urge organized faculty groups to become a part of the mainstream of organized labour in Canada. The affiliation of faculty associations will enable academics to work jointly with other employees on the campus as well as other workers in the city, province, or throughout Canada.

4. By joining organized labour, faculty will then become part of the real outside world instead of the perpetual world of Alice in Wonderland and Academia. Given that most Quebec University faculty are affiliated either to the CSN or CEQ, that is, the mainstream of Labour, would lead one to the conclusion that there is still hope for Faculty Unions in English Canada to join the mainstream of organized Labour. 


\section{CONCLUSIONS}

Academics like Alice in Wonderland are apt to ask, «Would you tell me, please, which way I ought to go from ? « But that, said the cat, «depends a good deal on where you want to get to.»

If Faculty Unionization in the long term is to have any permanent and deep significance it will be because Faculty Unions and faculty members desire, need and identify with a broader community of interests outside the academic world and are able to transform themselves from being a middle-class vested interest group into a group which has consciously choosen to join the mainstream of Labour. Should these links between Faculty Unions and the mainstream of the real world be forged, it will be the small concrete steps towards a broader transformation of the University and the purpose it plays in our Society.

\section{Travail et Société \\ Revue trimestrielle de l'Institut international d'études sociales, Genève, Suisse}

SOMMAIRE DU VOL. $1, \mathrm{~N}^{\circ} 1$, JANVIER 1976

Notes de l'éditeur -L'Institut international d'études sociales: Plans et perspectives, par Albert Tévoédjrè - Emploi et répartition du revenu: La voie à suivre, par Francis Blanchard - Facteurs stratégiques des systèmes de relations professionnelles: L'industrie métallurgique, par Milton Derber - La qualité de la vie professionnelle: Évolution au Japon, par Shin-ichi Takezwa - Les positions des syndicats français et italiens face à l' "humanisation » du travail, par Yves Delamotte - Les marchés urbains de l'emploi et leur fonctionnement dans les pays du Tiers-Monde, par Teshome Mulat - Le syndicalisme dans les sociétés multiraciales et ses répercussions sur l'économie politique - Une analyse comparative portant sur la Malaisie, la Trinité et la Zambie, par W. Richard Jacobs - Les migrations internationales et la conjoncture présente, par Georges Tapinos - Initiation des cadres sociaux aux problèmes de population: Évolution d'une expérience internationale, par $D^{r}$ J.O.N. Eze - Nouvelles de l'Institut - Nouvelles de nos correspondants.

Abonnement annue!: \$15.95. Travail et Société, c.p. 6, CH-1211 Genève, Suisse. 